\title{
REVIEWING THE STATUS OF AGRICULTURAL PRODUCTION IN BANGLADESH FROM A FOOD SECURITY PERSPECTIVE
}

\author{
Ghose Bishwajit, Researcher \\ Tongji Medical College, Wuhan, China \\ E-mail: brammaputram@gmail.com \\ Razib Barmon, Researcher \\ Bangladesh Agricultural University, Mymensingh, Bangladesh \\ E-mail: razib.bau@gmail.com \\ Sharmistha Ghosh, Researcher \\ Huazhong University of Science and Technology, Wuhan, China \\ E-mail: tandramoni@gmail.com
}

\begin{abstract}
This paper aims to review the major food security issues in Bangladesh, with a brief reference to its past trend in agricultural output, constraints, and challenges in the coming decades. Food security relates directly to nutrition and health of a population which consequently influences a nation's socio-economic status. Despite Bangladesh has changed its status from a country with chronic food shortages to a self-sufficient one, it still faces foodsecurity challenges. Few non-agricultural factors are identified as equally responsible for aggravating the food insecurity scenario. Since its independence in 1971, the country has constantly been facing issues like high population growth, political unrest, natural disasters which are contributing to food insecurity. Though industrialization is the order of the modern economy, agriculture remains the lifeblood of food security, especially for predominantly agrarian economies like Bangladesh. And this truth must be emphasized and implemented accordingly so that the predicted food crisis in near future can be successfully avoided. This article aims to review the performance of different agricultural sectors and to identify major setbacks to achieving food security in Bangladesh. This study is based on previously published researches on various food security issues in the context of Bangladesh.
\end{abstract}

\section{KEY WORDS}

Food security; Bangladesh; Agriculture; Poverty; Rice; Fisheries.

Since the World Food Conference of 1974, the concept of food security has evolved, multiplied and diversified. Classically, food security is thought of as being related to availability and access to adequate food. Yet, food security to a great extent is influenced by non-food elements that to a great extent impacts food production, accessibility and availability such as unplanned urbanization, income inequality, overpopulation, ecosystem degradation, animal health, and environmental factors. Bangladesh has experienced a remarkable increase in domestic food production, but continuing constraints on access to food and inadequacy of household and national incomes to purchase food, instability of supply and demand, as well as natural and man-made disasters are barriers to national food security. According to WHO definition, Food security exists when all people, at all times, have physical and economic access to sufficient, safe and nutritious food to meet their dietary needs and food preferences for an active and healthy life (The World Food Summit, 1996). Food security is an integrated concept revolving around four areas, namely the availability of food, the stability of supplies, access to such supplies and a correct biological use of foods. Thus food security by nature is a complex matter. Bangladesh has managed to triple its rice production since its independence, from 10 million MT in 1971 to over 32 million MT today. 8.44 million ha of the land are irrigated, which is over 7 times more than in 1990 (Bangladesh Agriculture Statistics, 2013). Modern varieties have been introduced on $75 \%$ of the total rice cropped area. Bangladesh is now world's sixth largest producer of rice which accounts for $77 \%$ of agricultural land use (irri.org, 2013). However these figures tell little 
about the future food production capacities as Bangladesh is identified as one the countries to be most seriously affected by climate change. Agricultural experts suggest that, despite production increases, Bangladesh still needs to increase and diversify agricultural output. To improve the availability of food, investments are needed to intensify and diversify food production and increase its sustainability [14]. To prepare for the predicted challenge to feed the huge population, policy makers must prioritize several critical items such as increasing productive capacity, maintaining a sustainable buffer stock of staple food grains, reinforcing agricultural R\&D, strengthening regional and international trade to better cope with increased commodity prices, and weather-related food supply shocks. At present some 148.80 million people are feeding themselves on about 18 million acres of farm land. The area of cultivated land cannot be extended much, but population will be about 194.4million in 40 years from now, according to a UN Medium Variant Projection. Number of persons per net cultivated acre will increase from 8.15 persons in 2010 to 11.0persons in 2050.

Agricultural production and food security in Bangladesh in recent years. Agriculture is the largest sector of Bangladesh's economy employing about $65 \%$ of the current labor force and accounting for around one fourth of the total GDP. The annual rice production is estimated to be 26.53 million tons [4], while fish production is 2.32 million tons [5]. In 20092010 , agriculture accounted for $23.5 \%$ of the country's GDP. Average share of agriculture to total GDP is $26.13 \%$ in Bangladesh since 1980 with a highest $32.77 \%$ in 1985 and a minimum of $18.29 \%$ in 2011 [15] and is therefore considered a lifeline of the Bangladesh economy. Table 1 indicates the importance of agriculture in the economy of Bangladesh.

Table 1 - Contribution of Agricultural sector in the economy

\begin{tabular}{|cccccc} 
Year & 1980 & 1990 & 2000 & 2010 & 2011 \\
Agriculture, value added (\% of GDP) & 31.55 & 30.25 & 25.51 & 18.59 & 18.29 \\
Agriculture, value added (annual \% growth) & 0.16 & 9.37 & 7.38 & 5.24 & 5.13
\end{tabular}

In recent years the agriculture sector has maintained an average annual growth of around 3 percent. However, agricultural production is under pressure from increasing demands for food with gradually decreasing resources.

Cereal grain and pulses. The structure of the agricultural sector in Bangladesh, as is the case with most other South Asian nations, is largely directed toward the cereal sector. Among cereals, the primary position is occupied by rice with about 80 percent of the total arable land is dedicated to rice cultivation. Thus rice boasts to be the primary crop for Bangladesh's entire agricultural sector and is also the staple item in Bangladeshi diets. Rice supply in 2015 is expected to be in the range of 31.2 to 35.2 million tons, and it is likely to grow to 39 million tons by 2030. It is projected that Bangladesh will be able to supply its own cereal grain at least till 2020. [Figure 3]. In 2000 to 2001, rice alone occupied $75 \%$ of the cultivable land [10] in Bangladesh which increased to $79.4 \%$ in 2008 [11]. In 2011, Bangladesh produced an all time record of 34.25 million tons of rice [12]. Rice also accounts for $94 \%$ of the cereals consumed and constitutes $92 \%$ of the annual food grain production [13]. During the period of 2006-2008, the share of cereals in the total value of agricultural output was 53\% [16]. Though Bangladesh has achieved significant progress in agriculture, especially with respect to rice production and yields, the demand for rice still outstrips domestic production (Table 2), and the country remains a net importer of rice [29].

Table 2 - Recent production and import status of rice in Bangladesh*

\begin{tabular}{|c|c|c|c|}
\hline Year & Total import of rice (1000 MT) & Total domestic production (1000 MT) & Area harvested (1000 ha) \\
\hline 2009 & 92 & 31 & 11600 \\
\hline 2010 & 1308 & 31.7 & 11700 \\
\hline 2011 & 563 & 33.7 & 11720 \\
\hline 2012 & 40 & 34 & 11650 \\
\hline
\end{tabular}

* Calculated from:

(1) United States department of Agriculture, USDA, http://www.indexmundi.com/agriculture/?country=bd\&graph=production;

(2) World rice statistics, IRRI. www.irri.org. 
With annual population growth of 1.8 million people, Bangladesh requires approximately an additional 300,000 metric tons of rice a year [18]. With growing population, planning for future cereal production to meet food security challenges would require projections of future supply and demand for cereals. Pulses are vital components in diversification of Bangladesh's predominantly rice-based cropping system. On average 550,000 tons of pulses are produced in Bangladesh every year. Lentil is the second most important pulse crop in terms of area (154,000 ha) and production $(116,000 \mathrm{t})$, but ranks the highest in consumer preference and total consumption [17]. The research institute has released 61 high-yielding modern varieties of rice since 1970, and 80 percent of the country's rice-growing land is currently cultivated with BRRI-developed varieties. Of the new rice varieties developed by the rice institute, hybrid varieties had yields of 6.5 to 9 tonnes per hectare, compared with 4 to 7.5 tonnes per hectare from other varieties. Despite their high yield, Bangladeshi farmers are less interested in growing hybrid varieties because producing and collecting seeds is more complicated.

Fisheries and livestock development. The role of fisheries and livestock sub-sector is very crucial for the economic development and food security in Bangladesh. Livestock and fisheries together contribute $3.3 \%$ of the GDP and $10.33 \%$ of the agriculture sector and provide daily dietary protein and milk requirements of the people.

Figure 1: Situation of food price inflation in Bangladesh

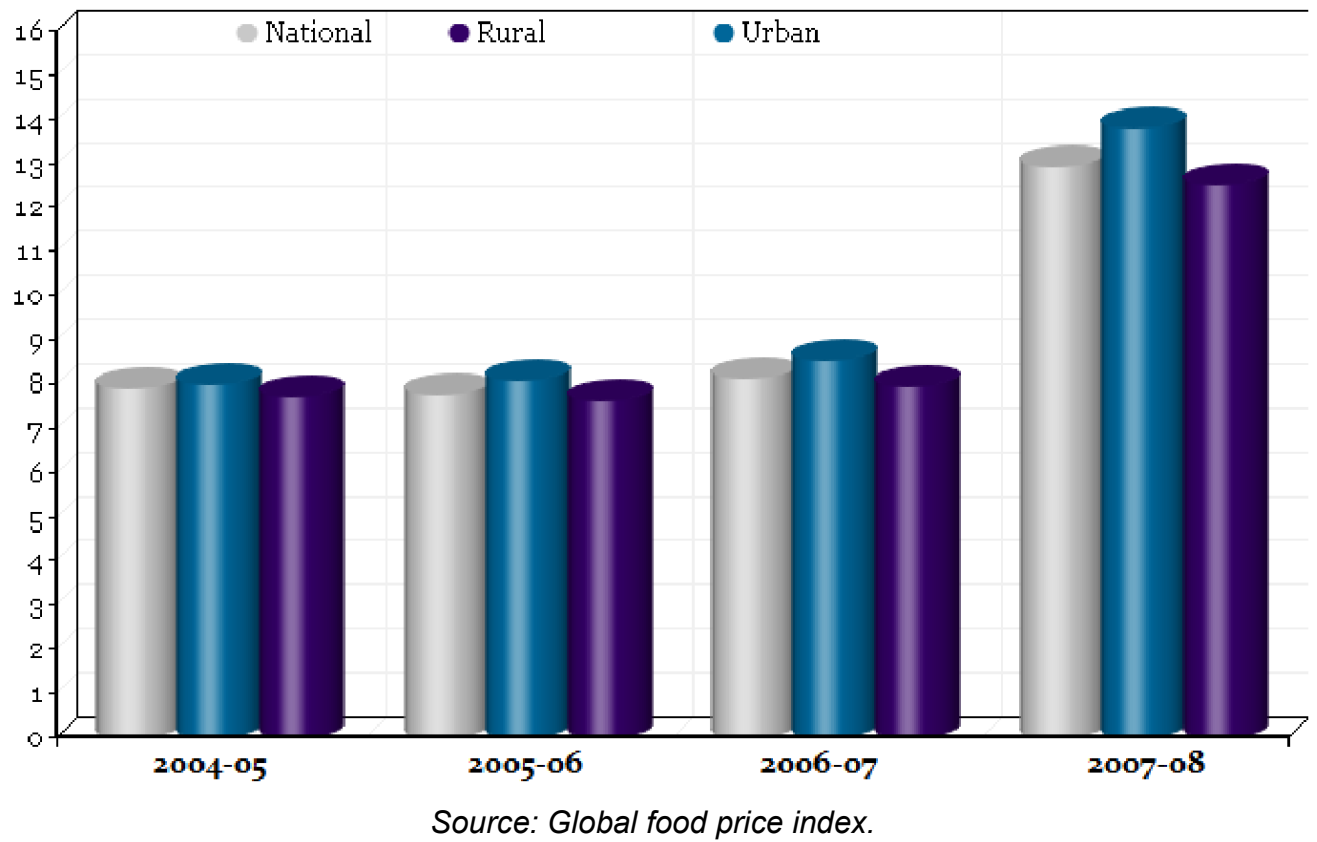

Figure 2: Bangladesh's share in global GDP

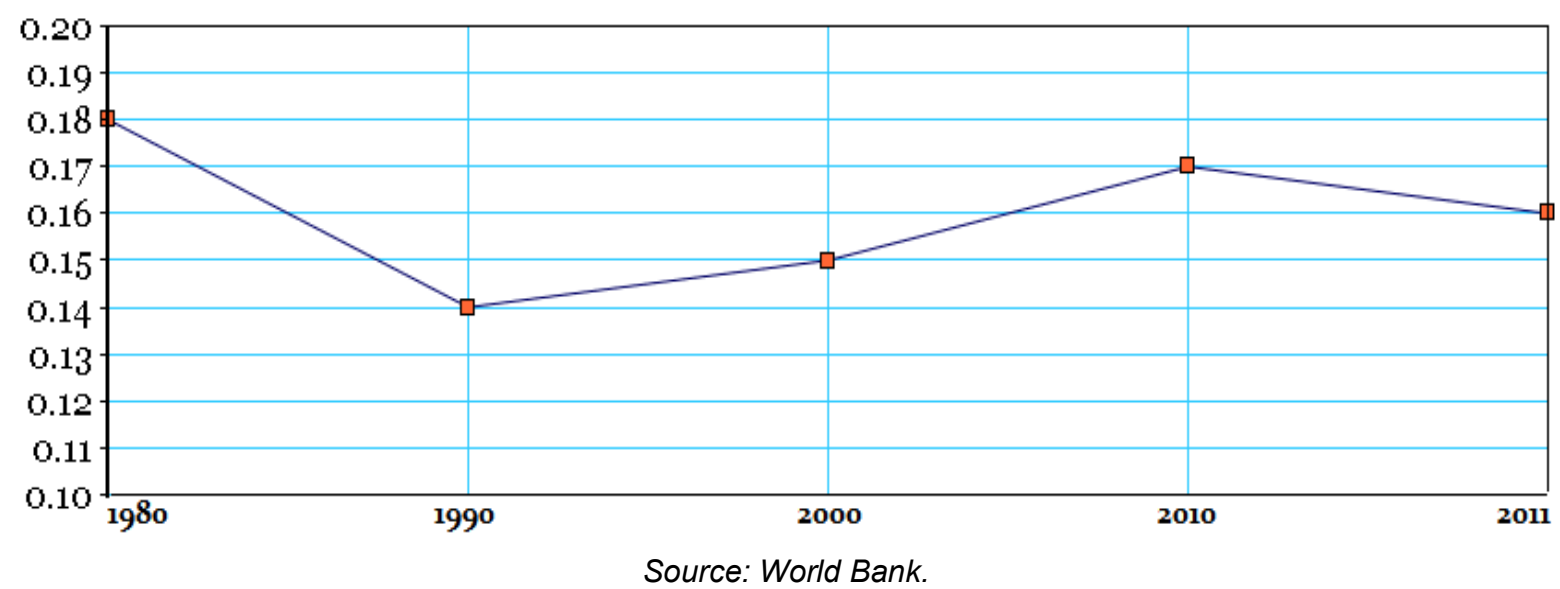


Figure 3: Projected food grain production and requirement

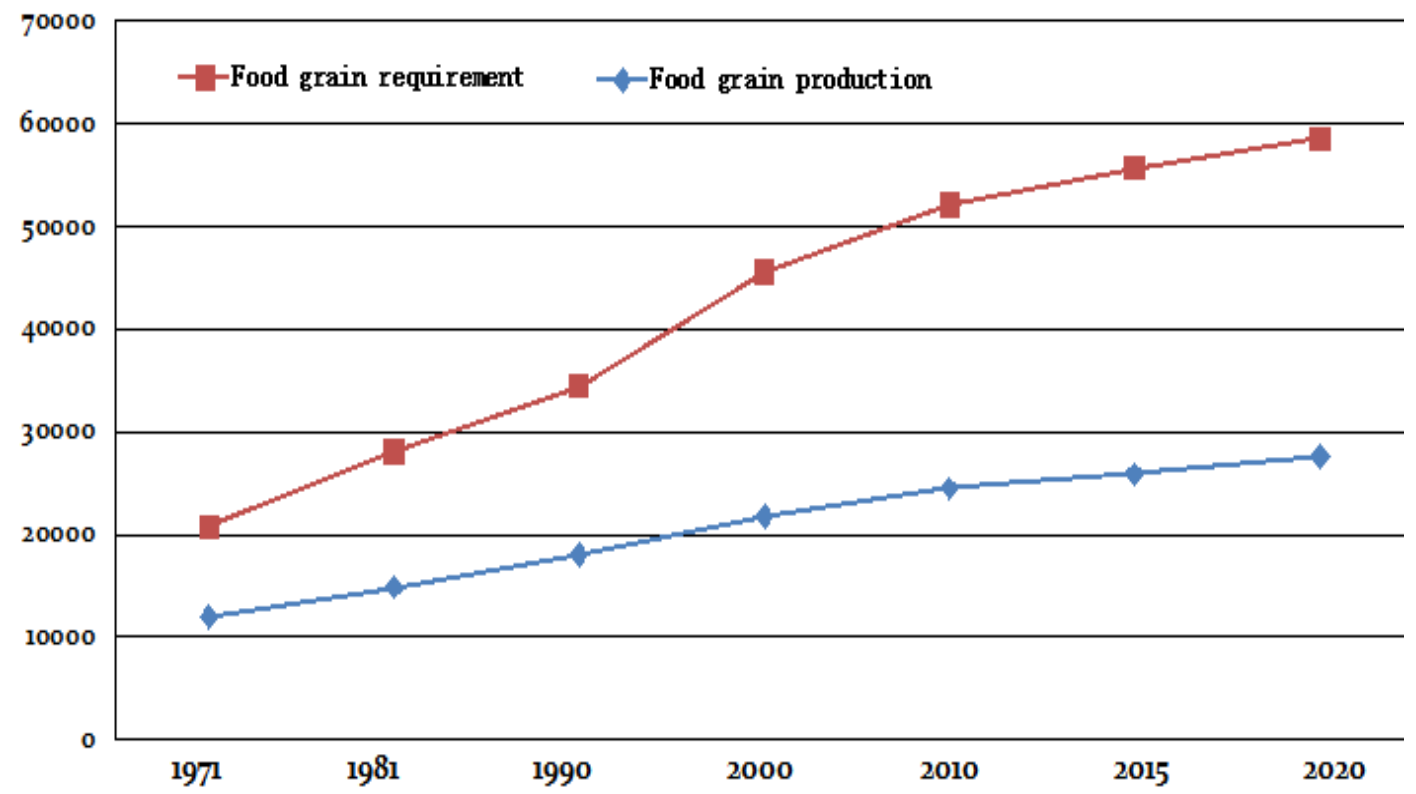

Source: Bangladesh Bureau of Statics, 2010.

Figure 4: Trend in fish production in Bangladesh

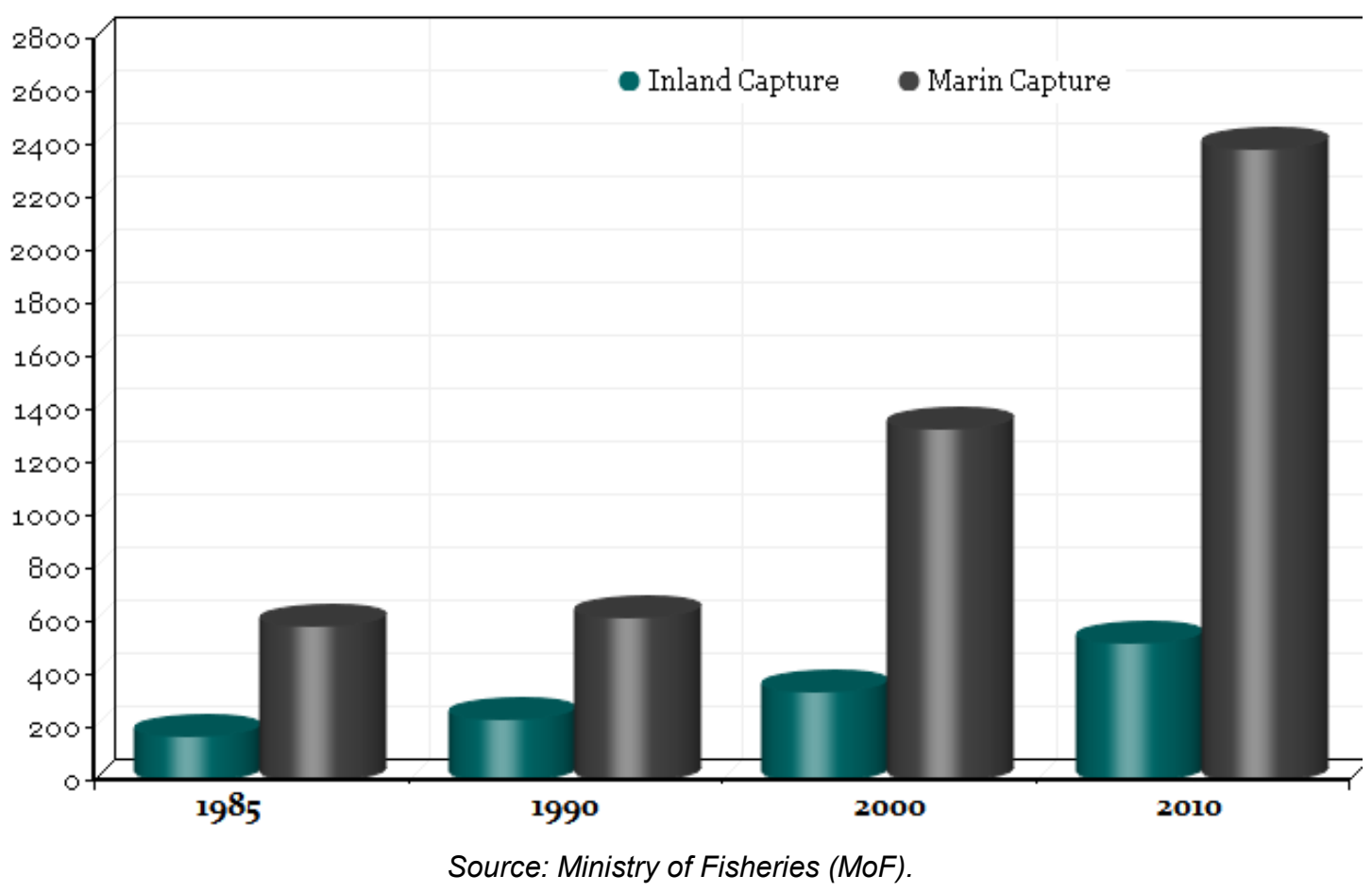

Cattle plays multiple roles in generating income and ensuring food security for many rural households. Although the contribution of livestock sub-sector is comparatively low in the country's total gross domestic product (GDP), it employs about 20 per cent of the rural labor force. This requires urgent and rapid development of livestock sub-sector in general and growth of livestock products in particular, in the future. The major challenges for the development of livestock sub-sector in Bangladesh are lack of feed, incidence of disease, and poor genetic stock. Therefore agribusiness relating to livestock requires all sorts of support including innovative researches on livestock development. There are about 22.4 
million goats in Bangladesh, and the production trend has been increasing with the growth rate of $2.4 \%$ [9].

Figure 4 shows the trend of marine and inland capture in Bangladesh. Bangladesh ranks third among the world's largest inland fish producing countries after China and India. Bangladeshi people are popularly referred to as "Macche-Bhate Bangali" or "fish and rice makes a Bengali. There are 300 species of fish and 20 species of prawns in Bangladesh [6]. Bangladesh is considered one of the most suitable countries in the world for farming of freshwater prawn (Macrobrachium rosenbergii) [19]. Shrimp farming in the south and southeastern coastal belt of Bangladesh began in the early 1970s. From less than 20,000 ha of brackish water ponds in 1980 and the area under cultivation expanded to approximately 140,000 ha by 1995 [24]. A sub-tropical climate and a vast area of shallow water bodies provide a unique opportunity for prawn and shrimp production [20-21]. For many people in Bangladesh small-scale fish farming is the key to generating income and the main source of dietary protein. In Bangladesh, total fish production was estimated at 2.1 million tons in 2005 of which $44 \%$ from freshwater aquaculture, $34 \%$ from inland capture fisheries, and $22 \%$ from marine fisheries [8]. Though fish is known to form an intrinsic and essential part of Bangladesh's food culture, there is a huge gap of fish consumption between the national average and at different levels of society. According to a 2003 report by Department of Fisheries (DoF), national average fish consumption is about $37 \mathrm{~g}$ per capita per day $(13 \mathrm{~kg}$ per year). However, the gender, wealth-class and locality have altogether been ignored in the process. There is likely to be a big gap among male-female, rich-poor and rural-urban people in per capita fish consumption. Traditionally, women and girl children are the least privileged group to eat fish in rural households. Thus there remains a big challenge in making fish available for consumption by females in equal quantity to the males in rural and poor society.

Major food security issues in Bangladesh. Bangladesh is the most densely populated large country in the world. Demographic trends indicate that this number will grow to around 220 million by 2050 . Bangladesh is currently experiencing rapid population growth and on the brink of severe food shortages in near future. A number of interrelated factors contribute to food insecurity in Bangladesh, poverty being the most prominent of all. In the dimension of food supply and availability, the most crucial challenges are increasing demand for the ever growing population, seasonal food scarcity, climate change and environmental degradation. Though its a global issue, it must initially be dealt by scrutinizing the causes that underlie food insecurity at household and national level. Food insecurity has a range of negative consequences on public health which in turn induces poverty. Studies have shown that food insecure people are more vulnerable to developing diabetes, cardiovascular diseases and other chronic health complications [25-27]. These factors not only pose economic burden at household level, but also on the overall economy by reducing active labor force, decreasing physical and mental performance. Apart from that, seasonal food shortage and high food prices are seriously affecting the food availability and accessibility of the poor and middle class especially in the northern region of the country.

The poverty-malnutrition nexus. Bangladesh is one of the poorest countries in the world and despite its recent strides in GDP growth it remains remarkably low when compared to the global scale [Figure 2]. Almost 40 percent of people in rural Bangladesh live on less than $\$ 1.25$ per day and 60 percent of that income is spent on food. Table 3 shows different aspects of poverty in Bangladesh. Poverty and malnutrition appears to be largely a rural phenomenon in Bangladesh and though huge difference exists across economic groups and gender.

Table 3 - Poverty dynamics of Bangladesh

\begin{tabular}{|c|c|c|c|c|}
\hline Year & 1996 & 2000 & 2005 & 2010 \\
\hline Poverty headcount ratio at national poverty line ( $\%$ of population) & 50.10 & 48.90 & 40.00 & 31.51 \\
\hline Poverty headcount ratio at $\$ 1.25$ a day (PPP) (\% of population) & 60.91 & 58.59 & 50.47 & 43.25 \\
\hline Poverty gap at $\$ 1.25$ a day (PPP) $(\%)$ & 19.93 & 18.61 & 14.17 & 11.17 \\
\hline Income share held by lowest $20 \%$ & 8.66 & 8.66 & 8.79 & 8.88 \\
\hline Gini index & 33.46 & 33.36 & 33.22 & 33.12 \\
\hline
\end{tabular}

Source: Adapted from World Bank report, Global Poverty Working Group. Data are based on World Bank's poverty assessments and poverty Reduction Strategies in Bangladesh. 
Food insecurity is not only a result of insufficient food production and inadequate distribution, but also of the financial inability of the poor to purchase sufficient food. Bangladesh has made appreciable progress in reducing the percentage of population living below $1.25 \$$ a day from $59 \%$ in $1991-92$ to $31.5 \%$ in 2010 . However, more than 17 percent of the population is still extremely poor. According to a FAO 2012 report, more than 40 million Bangladeshis are undernourished and don't have access to adequate amounts of safe, nutritious food to sustain a healthy and productive life. Bangladesh is ranked 129th out of 169 countries in the 2010 Human development Index (HDI), and 68th in a list of 79 countries in the 2012 Global Hunger Index (GHI). For those making less than US $\$ 1.25$ a day, access to adequate food from the market is often too costly. More than 90 percent of rural Bangladeshis don't get sufficient level of dietary vitamin-A and iron. Annually, under-nutrition contributes to more than a third of child deaths and to at least a fifth of maternal deaths in Bangladesh. As a result, malnutrition in Bangladesh remains among the highest in the world. Malnourishment leads to poor health hence individuals fail to provide for their families. Chronic hunger produces an array of outcomes that perpetuate malnutrition, reduce the ability of adults to work and to give birth to healthy children, and erode children's ability to learn and lead productive and healthy lives. Reduced performance at professional level undermines a country's real potential for socio-economic development. The two main reasons why livelihood and food security issues remain critical in Bangladesh are, (1) the heavy dependence of the majority of the population on the agricultural sector for employment and (2) the large number of undernourished people, the majority of whom are below the poverty line and spend a considerable proportion of their total income on food. Increased food production alone never going to bring significant progress in combating hunger and malnutrition if it is not combined with higher incomes and improved livelihoods for the poorest.

High food price. The 2008 price hike [Figure 1] went on to worsen the situation leading to the number of food insecure people (less than $2,122 \mathrm{kcal} / \mathrm{day}$ ) to increase by 7.5 million and the number of severely food insecure people (less than 1,805 kcal/day) to increase by 6.9 million. During 2010-2011 period, price of rice in Bangladesh has increased by close to $30 \%$, flour by $50 \%$, lentils by $15 \%$ and chicken by $37 \%$. More recently, since last fall, foodgrain prices began shooting up again, reaching levels comparable to that of 2008 thus having implications for the health and well being of households and communities particularly the poor and vulnerable groups of mothers and children. In 2011, consumer prices rose 11.97 percent in September from a year earlier, after gaining 11.29 percent the previous month. Food inflation quickened to 13.8 percent in September from 12.7 percent in the previous month. When food prices increase, poor people purchase more of the lower cost staple food and less of the complementary sources of vitamins and minerals, which results in both chronic and acute malnutrition. A mid-1990 study Bouis and colleagues in rural Bangladesh has shown that a 50 percent increase in food prices results in a decrease in energy intake of $5-15 \%$ and a drop in iron intake of $10-30 \%$. Street blockade by garments workers demanding better wages to meet high food prices has been a striking scenario in Bangladesh during last five years. The poor are hit hardest during these price shocks as they spend more of their income on food. The price of rice is mostly controlled by middle-men not by market factors such as demand and supply. Moreover, the structure of domestic rice market is very complex. The presence of restrictive business practices and other disruptive actions (such as deliberate supply shortage) in the rice market contribute to a significant gap between farm-gate price and consumer price of rice. Therefore, international speculation helped business elements make possible to create an artificial crisis in domestic rice market leading to a significant increase in food prices in recent years. The rural households suffer mostly from increased food price because they are net buyers of rice.

Climate change and natural disasters. Bangladesh is facing serious challenge from the climate change with direct impact on the coastal agriculture. Bangladesh is a low-lying riverine country and is ranked first among countries vulnerable to climate change because of geophysical position and poor socioeconomic conditions [23]. Securing world food security in light of the impact of climate change may be one of the biggest challenges of the century. 
Bangladesh is one of the most disaster-prone countries in the world, and climate changerelated disasters, such as cyclones and floods, lean season crises, and drought, are likely to continue to undermine overall development efforts. In 2007, after two floods and Sidr (cyclone), food security was severely threatened. Losses for rice production were estimated at 1.8 million MT, enough to feed over 10 million people for a year, while facing 15 tons per year of food shortages per year. Although Bangladesh is mainly depends on it but not yet self sufficient on food because of agricultural losses due to natural disasters every year. In the past, the rural poor used to catch small fish from ditches, canals and flood plains at little or no cost. This is no longer possible due to environmental degradation. Thus Bangladesh's high poverty and undernutrition rates are exacerbated by frequent natural disasters and consequent loss of agricultural crops. Bangladesh has 8.774 million hectares of cultivable land, of which $88 \%$ is cultivated, so there is a limited scope to expand the cultivated area [30].

Seasonal food insecurity. Monga or seasonal food insecurity is not a new phenomenon in rural Bangladesh, but the topic just started to catch public interest in recent years. To the NGOs and other actors in the development process Monga is now an important concern, for which they collect funds and implement program. The basic explanation of the Monga phenomenon is widely known: employment and income opportunities of the rural poor strongly decrease between transplantation and harvest of paddy. Monga affects ecologically vulnerable and economically weak parts of north-western Bangladesh, primarily caused by an employment and income deficit. It mainly affects those rural poor, who have an undiversified income that is directly or indirectly based on agriculture. Actors, who are involved in the issue, have built up a good knowledge about the problem, but this knowledge is so far not being adequately shared and not accessible. Though Monga is also understood as a synonym for seasonal food insecurity in general, it doesn't necessarily indicate that there is no food insecurity in other regions of Bangladesh. Table 4 describes that cereal production has been increasing noticeable since 1980 and the country became self-sufficient in food grain production from 1900-2000 (Talukder, 2005).

Table 4 - Agricultural production (In 1000 MT)

\begin{tabular}{ccccccc} 
n/n & 1980 & 1990 & 2000 & 2010 & 2013 \\
Rice (milled) & 13,883 & 17852 & 25,086 & 31,700 & 34,200 \\
\hline Wheat & 1093 & 1004 & 1673 & 972 & 1180 \\
\hline
\end{tabular}

Source: 1) USDA, 2011, 2) Yearbook of Agricultural Statistics of Bangladesh. (N.A: Data not available)

But this success in production is not felt across all regions equally and thus production status doesn't quite explain the food security problems in Bangladesh. During the lean seasons (March-April and October-November) prior to harvesting the main rice crops, job opportunities are low and resulting in low wage rates, while food prices are at their highest. Therefore, income derived from non-agricultural sources can provide a possible safeguard against the cyclical nature of agricultural income and therefore can substantially improve household food security.

\section{CONCLUSIONS}

Even though nature is bountiful in Bangladesh for agricultural production, its poor exploitation, compounded by various political and socio-economic factors are preventing the country to be food secured. Though several international bodies are currently involving in some food security programs in Bangladesh, food security issues must first be addressed by taking measures locally in order to make the outcomes sustainable. Also as a consequence of economic growth, current rice cultivation areas are likely to be lost to urban expansion. Accordingly, sufficient production to meet future demand will have to come from smaller and smaller areas, particularly if diversification is to be made possible while keeping rice prices affordable to poor consumers. As population continues to grow and to urbanize at 
unprecedented rates, food insecurity in Bangladesh is going to worsen rather than improve unless swift action is taken. Bangladeshi farmers need to grow more food using less land, water, while overcoming new challenges from climate change. Policy makers and agriculturalists need to act in conjunction with local farmers, private sector, staff from other sectors and other departments, and the think-tanks in attempt to avoid the threats of food insecurity in imminent future. As majority of the population is located in the rural areas, where even if the country is nationally food secure the situation is worse at the grass-root level due mostly to poor transport facilities and lack of effective measure to ensure proper distribution of food among the disadvantaged citizens. The fact of the matter is that, for a country like Bangladesh with remarkably high socio-economic disparities, household food security should be prioritized over the food security at national level. Those working on food security in Bangladesh will need to talk not only to policy makers in the engineering sectors, but also engage in a dialogue with farmers at the local levels and the think-tanks as well. Finally, a peaceful and stable political and socio-economic environment is vital to attach adequate priority to food security. Therefore, to facilitate effective planning, projections of future supply and demand for food is of paramount importance.

\section{REFERENCES}

[1] The World Food Summit (1996), Rome, Italy.

[2] Bangladesh Agriculture Statistics (2013), http://www.agriculturebd.com

[3] Rice in Bangladesh (2013), http://irri.org/index.php?option=com_k2\&view=item\&id=10824:rice-in-bangladesh

[4] Rice statistics in Bangladesh (2006). Bangladesh Rice Knowledge Bank (BRKB), Bangladesh Rice Research Institute (BRRI), Gazipur, Bangladesh.

[5] Department of Fisheries (DOF) (2007). Fishery statistical yearbook of Bangladesh 2005-2006. Fisheries Resources Survey System, Department of Fisheries, Dhaka, Bangladesh.

[6] Rahman, A.K.A. (1989). Freshwater Fishes in Bangladesh. Zoological Society of Bangladesh, Dhaka.

[7] Handbook of Agricultural Statistics, Bangladesh. 2007.

[8] Nesar, A., Abdul, W., and Shakuntala H. (2007), 'Integrated aquaculture-agriculture in Bangladesh', Aquaculture, Vol XII, No. 1.

[9] Bangladesh Department of Finance. Bangladesh Economic Review 2009.

[10] Sustainable Development Networking Program (SDNP): Agricultural database.Dhaka, Bangladesh (2001), http://www.sdnbd.org/sdi/issues/agriculture/index.htm.

[11] FAOMFP CFSAM 2008 report; (2008).

[12] The financial express (2012), Vol 20, No 413. Dhaka.

[13] Mohammad C. (2009), 'Sustainability of accelerated rice production in Bangladesh: technological issues and the environment', Bangladesh Journal of Agriculture, Vol 34, No 3, pp 523.

[14] The National Food Policy and Plan of Action. Working paper series, (2001). Food Planning and Monitoring Unit (FPMU), Ministry of Food and Disaster Management, www.nfpcsp.org.

[15] Bangladesh: Economy Indicators (2012). World Bank. http://www.theglobaleconomy.com/Bangladesh/indicator-NV.AGR.TOTL.ZS/

[16] FAO Country report, Bangladesh. (2010).

[17] Bangladesh Bureau of Statistics, BBS, (2002).

[18] Grain and Feed Annual Bangladesh (2013). GAIN Report Number: BG30043/28/20132013.

[19] World Fish Center Fish and Human Nutrition, The World Fish Center, Penang, Malaysia (2011).

[20] Ahmed, N., Demaine, H., and Muir, J.F. (2008), 'Freshwater prawn farming in Bangladesh: history, present status and future prospects', Aquaculture Research, Vol 39, pp 806-819 
[22] Islam, M.S. (2008), 'From pond to plate: towards a twin-driven commodity chain in Bangladesh shrimp aquaculture', Food Policy, Vol 33, pp 209-223.

[23] Harmeling, S. (2010). 'Global Climate Risk Index 2010: Who Is the Most Vulnerable? Weather-related Loss Events Since 1990 and How Copenhagen Needs to Responds German watch', Bonn.

[24] Wahab, M.A. (2003). 'Environmental and socioeconomic impact of shrimp farming in Bangladesh', pp. 19-32.

[25] Seligman, Bindman, Vittinghoff, et al (2007). 'Food Insecurity is Associated with Diabetes Mellitus: Results from the National Health Examination and Nutritional Examination Survey 1999-2002', Journal of General Internal Medicine, Vol 22, pp 1018-1023.

[26] Nelson, Cunningham, Andersen, et al (2001). 'Is Food Insufficiency Associated with Health Status and Health Care Utilization Among Adults with Diabetes?', Journal of General Internal Medicine, Vol 16, pp 404-411.

[27] Seligman, Laraia, and Kushel (2009). 'Food Insecurity Is Associated with Chronic Disease among Low-Income NHANES Participants', Journal of Nutrition, Vol 140, pp 304-310.

[28] R K Talukder, R.K. (2005). 'Food Security, Self-sufficiency and Nutrition Gap in Bangladesh' The Bangladesh Development Studies, Vol. 31, pp. 35-62.

[29] Supply and Demand for Cereals in Bangladesh, 2010-2030, Food Planning and Monitoring Unit 2009. http://www.ifpri.org/sites/default/files/publications/

[30] Peter, K.S. and Zunaid, A.K. (2008), 'Population Challenges for Bangladesh in the Coming Decades', Journal of Health, Population, and Nutrition., Vol 26, No 3, pp. 261272. 